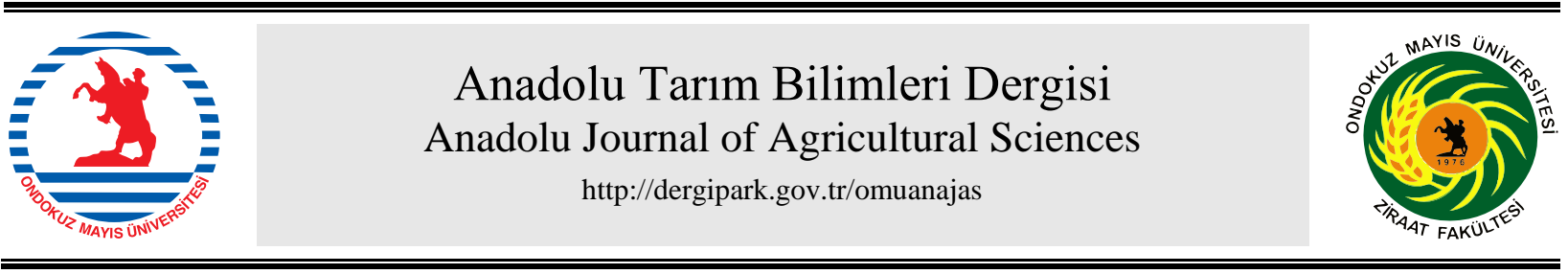

Research

Anadolu Tarım Bilim. Derg./Anadolu J Agr Sci, 33 (2018) ISSN: 1308-8750 (Print) 1308-8769 (Online) doi:10.7161/omuanajas.405418

\title{
Variability of organoleptic quality of genotypes of Arabica coffee
}

\author{
Sabam Malau ${ }^{a *}$, Albiner Siagian ${ }^{\mathrm{b}}$, Bilter Sirait $^{\mathrm{c}}$, Himsar Ambarita $^{\mathrm{b}}$, Samse Pandiangan ${ }^{\mathrm{a}}$, \\ Maria Rumondang Sihotanga, Benika Naibaho ${ }^{\mathrm{a}}$, Rosnawyta Simanjuntak ${ }^{\mathrm{a}}$ \\ ${ }^{a}$ Nommensen HKBP University, Jalan Sutomo 4-A, Medan 20234, Indonesia \\ ${ }^{b}$ North Sumatra University, Jalan Dr. T. Mansur No. 9, Kampus Padang Bulan, Medan 20155, Indonesia \\ ${ }^{c}$ Darma Agung University, Jl. Doktor TD Pardede No.21, Petisah Hulu, Medan 20153, Indonesia \\ *corresponding author: sabam.malau@uhn.ac.id \\ Received 13/03/2018 Accepted 28/09/2018
}

\begin{abstract}
Beverage quality of coffee is the most important for consumers. The objective of this research was to determine the genotypic and phenotypic variability of Arabica coffee (Coffea arabica L.). Nested design with three factors was used. The organoleptic quality of 28 genotypes was analyzed. This research revealed that most of the organoleptic qualities had low genotypic and phenotypic variations. Fragrance/aroma, flavor, aftertaste, acidity, body, uniformity, balance, sweetness, overall and total score showed low heritability and low genetic advance.
\end{abstract}

Keywords:

Genetic advance

Genotype

Heritability

Phenotype

Taste

(C) OMU ANAJAS 2018

\section{Introduction}

Comsumers look for coffee that fits their tastes. Beverage quality for certain people depends on the chemical contents of beans and organoleptic quality of coffee such as Germans and Swedes like very much coffee lighter and more acidity than Italian while Frence people living in the North prefer "Rio" taste referring to trichloroaniso (Leroy et al., 2006). Genotypic variation, heritability, and genetic advance of organoleptic qualities are essential for coffee breeding in order to find superior genotype that has the best taste. Several organoleptic qualites of Arabica coffee had moderate to high genotypic variability (Tessema et al., 2011; Kitila et al., 2011; Kathurima et al., 2015) and high heritability (WeldeMichael, 2015). Hence, selection for certain organoleptic quality may be conducted.

Arabica coffee was cultivated in North Sumatra Province of Indonesia since more than one hundred years ago and had expanded that coffee become an important economic commodity in this province (Mawardi et al., 2008; Wahyudi et al., 2016). This province has around 60,000 ha of Arabica coffee growing area and 151000 coffee farmers (households) (DGEC, 2015). As it contributed in amount of 49000 tons of green beans to the total production in Indonesia in amount of 170000 tons of green beans in the year 2013, this province is one of the largest producers of
Arabica coffee in Indonesia.

Beverage quality depends on many factors such as chemical contents of beans which is influenced by genotype and plant growth environment (climate conditions and soil properties), drying method, and cooking conditions.

For new cultivation and replanting of coffee, most of the coffee farmers in this province selected the seeds based solely on the agronomic performances of the growing plants. In the upcoming future, beverage qualities need to be considered as selection criterion. However, information on genetic components of organoleptic qualities of Arabica coffee plants found in this province was not yet available. Hence, the objectives of this research was to determine phenotypic and genotypic variability organoleptic quality of Arabica coffee plants found at coffee growing areas in North Sumatra. It was hypothesized that the organoleptic quality showed significant phenotypic and genotypic variability.

\section{Materials and Method}

\subsection{Data collection}

Organoleptic and physical quality of 28 genotypes of Arabica coffee were analyzed. To find these genotypes, nested design with three factors was used (Quinn and 
Keough, 2002). Seven districts (North Tapanuli, Tobasa, Humbanghas, Samosir, Simalungun, Dairi and Pakpak Bharat) and two subdistricts in each district were chosen. In each subdistrict, two coffee farms (as genotypes) were selected. Climate zone of district North Tapanuli, Tobasa, Humbanghas, Samosir, Simalungun, Dairi, and Pakpak Bharat are E1, E2, A1, D1, B1, D2, and C1, respectively. Large of the area in which sample was taken was around 18,381 square kilometers.

On each farm, 200-400 coffee plants were growing and not shaded. The genotypes were 6-7 years old of age with shoot of bronze-colored leaves and bearing red ripe fruits. The genotypes had harvest frequency of once in two weeks. Each farm was divided into four similar large subfarms (four samples).

All harvested ripe fruits were treated by using full washed method to produce green beans (Yusianto, 2008) whereby the moisture content of green bean was 14\%. Data of organoleptic qualities were obtained by using the Cupping Protocols of the Specialty Coffee Association of America (SCAA, 2009). Following the SCCA cuppping protocols, the green bean and roasted bean and grilled coffee were prepared. Roasted bean profile was a light to light-medium roast. Grilled coffee was 20 mesh. Five cups were used for each sample. In amount of 8.25 grams of grilled coffee in each cup. The boiled water with temperture of $930 \mathrm{C}$ was then poured into the cups.

Organoleptic qualities were the fragrance/aroma, flavor, aftertaste, acidity, body, uniformity, balance, clean cup, sweetness, overall, defect and total score. Fragrance and aroma are aromatic characteristics. Fragrance is the smell of the dry ground coffee while aroma is the smell of the coffee after being poured with hot water (93 0C). Flavor as the principal character of coffee is the combination of aroma, acidity and aftertaste. Flavor is the combination of all the sense of taste on the tongue and netro-nasal aroma that go from the mouth to nose. Aftertaste is the duration of positive flavor. Favorable acidity is attributed as brightness whereas unfavorable acidity is sour. Acidity contributes to the liveliness, sweetness, and fresh- fruit character of coffee. Body is the sensation of tactile thickness of liquid on the tongue and roof of the mouth. Balance is the harmony of flavor, aftertaste, acidity and body. Sweetness is the perception of the presence of carbohydrate and a pleasing fullness of flavor. Clean cup is an attribute of the absence of negative impressions caused by non-coffee like tastes or aromas. Uniformity describes the similarity of flavor of the different cups. Overall is the holistic sensory perception of all attributes rated by an individual taster. Defect is an off-flavor. Total score (maximum 100) as final score is the sum of the scores of all attributes. The panel of coffee taste testers comprised of Licenced Q Graider (the coffee taste testers are certified by the Coffee Quality Institute and the Specialty Coffee Association of America) and trained experienced coffee tasters. The taste tests were carried out twice with one week distance in the Cupping Laboratory of Goldenways Coffee Company in Medan. The average value was used for the variance analysis.

\subsection{Data analysis}

Corresponding mean squares were used to test the significance of each source of variations (Quinn and Keough, 2002). For example, F-ratio for genotype was obtained by dividing $\mathrm{MS}_{\mathrm{G}(\mathrm{L}(\mathrm{K}))}$ by $\mathrm{MS}_{\text {Error }}$ (Table 1). Espected mean square (EMS) was estimated by using the formulas of estimated variance component (EVC). Estimated variance of error $\left(\mathrm{s}^{2} E\right)$ was equal to mean square of error $\left(\mathrm{MS}_{\text {Error }}\right)$. Therefore, estimated variance of phenotype $\left(\mathrm{s}^{2} \mathrm{P}\right)$ is the sum of $\mathrm{s}^{2}{ }_{\mathrm{G}}$ with $\mathrm{s}^{2}$. Genotypic and phenotypic variation, heritability and genetic advance could then be calculated by using $\mathrm{s}^{2}$ and $\mathrm{s}^{2} \mathrm{P}$. Genotypic coefficient of variation (GCV) = $\left(\left(\left(\mathrm{s}_{\mathrm{G}}^{2}\right)^{0.5}\right) / \mathrm{m}\right) \times 100 \%$ and phenotypic coefficient of variation $(\mathrm{PCV})=\left(\left(\left(\mathrm{s}^{2} \mathrm{P}\right)^{0.5}\right) / \mathrm{m}\right) \times 100 \%$ whereby $\mathrm{m}$ is mean of phenotype (Mayo, 1987). Coefficient of heritability in broad sense $\left(\mathrm{H}^{2}{ }_{\mathrm{bs}}\right)=\mathrm{s}_{\mathrm{G}}^{2} / \mathrm{s}^{2} \mathrm{P}$, genetic advance $(\mathrm{GA})=(\mathrm{i})\left(\mathrm{s}^{2}\right)^{0.5}\left(H_{b s}^{2}\right)$ and GA in percentage of mean $(\mathrm{GAM})=(\mathrm{GA} / \mathrm{m}) \times 100 \%$ whereby $\mathrm{i}=2.063$ at selection intensity 5\% (Poehlman, 1987). GCV, PCV and GAM was interpreted as low $(<5 \%)$, moderate (5$10 \%)$ and high $(>10 \%) . \quad \mathrm{H}^{2}$ bs is identified as low $(<40 \%)$, moderate $(40-60 \%)$ and high $(>60 \%)$.

Table 1. Variance analysis estimation of nested design

\begin{tabular}{|c|c|c|c|c|c|}
\hline Source of variation & $\mathrm{df}$ & MS & F-ratio & EMS & EVC \\
\hline District $(\mathrm{K})$ & $a-1$ & $\mathrm{MS}_{\mathrm{K}}$ & $\mathrm{MS}_{\mathrm{K}} / \mathrm{MS}_{\mathrm{L}(\mathrm{K})}$ & $\begin{array}{c}\sigma_{E}^{2}+\mathrm{r} \sigma_{G}^{2}+ \\
\operatorname{rc} \sigma_{L}^{2}+ \\
\operatorname{rcb} \sigma_{K}^{2}\end{array}$ & $\mathrm{~s}^{2}{ }_{\mathrm{A}}=\left(\mathrm{MS}_{\mathrm{K}}-\mathrm{MS}_{\mathrm{L}(\mathrm{K})}\right) / \mathrm{rcb}$ \\
\hline $\begin{array}{l}\text { Subdistrict within District } \\
(\mathrm{L}(\mathrm{K}))\end{array}$ & $a(b-1)$ & $\mathrm{MS}_{\mathrm{L}(\mathrm{K})}$ & $\mathrm{MS}_{\mathrm{L}(\mathrm{K})} / \mathrm{MS}_{\mathrm{G}(\mathrm{L}(\mathrm{K}))}$ & $\begin{array}{c}\sigma_{E}^{2}+\mathrm{r} \sigma_{G}^{2}+ \\
\operatorname{rc} \sigma_{L}^{2}\end{array}$ & $\mathrm{~s}_{\mathrm{L}}^{2}=\left(\mathrm{MS}_{\mathrm{L}(\mathrm{K})}-\mathrm{MS}_{\mathrm{G}(\mathrm{L}(\mathrm{K})}\right) / \mathrm{rc}$ \\
\hline $\begin{array}{l}\text { Genotype within } \\
\text { subdistrict within district } \\
(\mathrm{G}(\mathrm{L}(\mathrm{K})))\end{array}$ & $\mathrm{ab}(\mathrm{c}-1)$ & $\mathrm{MS}_{\mathrm{G}(\mathrm{L}(\mathrm{K})}$ & $\mathrm{MS}_{\mathrm{G}(\mathrm{L}(\mathrm{K}))} / \mathrm{MS}_{\text {Error }}$ & $\sigma_{E}^{2}+\mathrm{r} \sigma_{G}^{2}$ & $\mathrm{~s}^{2} \mathrm{G}=\left(\mathrm{MS}_{\mathrm{G}(\mathrm{L}(\mathrm{K}))}-\mathrm{MS}_{\text {Error }}\right) / \mathrm{r}$ \\
\hline Error & $a b c(r-1)$ & $\mathrm{MS}_{\text {Error }}$ & & $\overline{\sigma_{E}^{2}}$ & $\mathrm{~s}_{E}^{2}=\mathrm{MS}_{\text {Error }}$ \\
\hline
\end{tabular}

$\mathrm{df}=$ degree of freedom, $\mathrm{a}=$ seven levels, $\mathrm{b}=$ two levels, $\mathrm{c}=$ two levels, $\mathrm{r}=$ four samples, MS = mean square, EMS = expected mean square, $\mathrm{EVC}=$ estimated variance component. 


\section{Result and Discussion}

The genotypes were significantly different $(\alpha=0.05)$ in aftertaste, acidity and sweetness, and highly significantly different $(\alpha=0.01)$ in fragrance/aroma, flavor, body, balance, overall and total score (Table 2).

By using $s^{2} \mathrm{G}$ and $\mathrm{s}^{2} \mathrm{P}$ (Table 3 ), the genetic components of each parameter were calculated (Table 4). Hundred bean weight had moderate genotypic variation and phenotypic variation, performed high heritability. Fragrance/aroma, flavor, aftertaste, acidity, body, uniformity, balance, sweetness, overall and total score had low genotypic variation. Sweetness had the highest genotypic variability. Uniformity and sweetness showed moderate phenotypic variation. Sweetness had the highest phenotypic variability. The result of this research showed that most of the attributes of organoleptic qualities had low variability of genetic components (Table 4).

Table 2. Analysis of variance of organoleptic and physical quality

\begin{tabular}{|c|c|c|c|c|c|c|c|}
\hline & $\begin{array}{l}\text { MS district } \\
(p=7 ; \mathrm{df}=6)\end{array}$ & $\begin{array}{l}\text { MS } \\
\text { subdistict } \\
(\mathrm{q}=2 ; \mathrm{df}=7)\end{array}$ & $\begin{array}{l}\text { MS } \\
\text { genotype } \\
(\mathrm{r}=2 ; \mathrm{df}=14)\end{array}$ & $\begin{array}{l}\text { MS error } \\
(\mathrm{df}=84)\end{array}$ & $\begin{array}{l}\text { F-ratio for } \\
\text { district }\end{array}$ & $\begin{array}{l}\text { F-ratio for } \\
\text { subdistrict }\end{array}$ & $\begin{array}{l}\text { F-ratio for } \\
\text { genotype }\end{array}$ \\
\hline \multicolumn{8}{|c|}{ Organoleptic quality } \\
\hline Fragrance/Aroma & 4.9126786 & 0.0332143 & 0.2542857 & 0.0916667 & $147.91 * *$ & $0.13 \mathrm{~ns}$ & $2.77 * *$ \\
\hline Flavor & 4.0285119 & 0.0959821 & 0.2709821 & 0.0882440 & $41.97 * *$ & $0.35 \mathrm{~ns}$ & $3.07 * *$ \\
\hline Aftertaste & 2.0701786 & 0.1074107 & 0.2331250 & 0.1063988 & $19.27 * *$ & $0.46 \mathrm{~ns}$ & $2.19 *$ \\
\hline Acidity & 2.1703571 & 0.0977679 & 0.1159821 & 0.0579464 & $22.20 * *$ & $0.84 \mathrm{~ns}$ & $2.00 *$ \\
\hline Body & 1.7810119 & 0.0202679 & 0.1788393 & 0.0637798 & $87.87 * *$ & $0.11 \mathrm{~ns}$ & $2.80 * *$ \\
\hline Uniformity & 7.6666667 & 2.0000000 & 0.7857143 & 0.5000000 & $3.83 \mathrm{~ns}$ & $2.55 \mathrm{~ns}$ & $1.57 \mathrm{~ns}$ \\
\hline Balance & 1.6350000 & 0.0391964 & 0.1766964 & 0.0678869 & $41.71 * *$ & $0.22 \mathrm{~ns}$ & $2.60 * *$ \\
\hline Clean cup & 1.5357143 & 1.9285714 & 1.0000000 & 0.6904762 & $0.80 \mathrm{~ns}$ & $1.93 \mathrm{~ns}$ & $1.45 \mathrm{~ns}$ \\
\hline Sweetness & 5.0357143 & 1.1785714 & 1.1785714 & 0.6071429 & $4.27 *$ & $1.00 \mathrm{~ns}$ & $1.94 *$ \\
\hline Overall & 2.6692560 & 0.1515179 & 0.2436607 & 0.0968750 & $17.62 * *$ & $0.62 \mathrm{~ns}$ & $2.52 * *$ \\
\hline Total score & 268.6943155 & 9.3326786 & 11.7748214 & 4.1076786 & $28.79 * *$ & $0.79 \mathrm{~ns}$ & $2.87 * *$ \\
\hline \multicolumn{8}{|l|}{ Physical quality } \\
\hline $\begin{array}{l}\text { Hundred bean } \\
\text { weight }(\mathrm{g})\end{array}$ & 24.4013717 & 4.0414375 & 3.2177554 & 0.4126583 & $6.04 *$ & $1.26 \mathrm{~ns}$ & $7.80 * *$ \\
\hline
\end{tabular}

Table 3. Estimated variance components of organoleptic and physical quality

\begin{tabular}{|c|c|c|c|c|c|}
\hline & $\begin{array}{l}\text { Estimated } \\
\text { varince } \\
\text { district }\left(s^{2}{ }_{D}\right)\end{array}$ of & $\begin{array}{l}\text { Estimated } \\
\text { varince of } \\
\text { subdistrict } \\
\left(s^{2}\right)\end{array}$ & $\begin{array}{l}\text { Estimated } \\
\text { variance of } \\
\text { genotype }\left(s_{G}^{2}\right)\end{array}$ & $\begin{array}{l}\text { Estimated } \\
\text { variance of error } \\
\left(s_{E}^{2}=\text { mean }\right. \\
\text { square of error) }\end{array}$ & $\begin{array}{l}\text { Estimated } \\
\text { variance of } \\
\text { phenotype } \\
\left(s_{P}^{2}\right) \\
\end{array}$ \\
\hline \multicolumn{6}{|c|}{ Organoleptic quality } \\
\hline Fragrance/Aroma & 0.3049665 & -0.0276339 & 0.0406548 & 0.0916667 & 0.1323214 \\
\hline Flavor & 0.2457831 & -0.0218750 & 0.0456845 & 0.0882440 & 0.1339286 \\
\hline Aftertaste & 0.12267299 & -0.01571429 & 0.0316815 & 0.1063988 & 0.1380804 \\
\hline Acidity & 0.12953683 & -0.00227679 & 0.0145089 & 0.0579464 & 0.0724554 \\
\hline Body & 0.1100465 & -0.0198214 & 0.0287649 & 0.0637798 & 0.0925446 \\
\hline Balance & 0.0997377 & -0.0171875 & 0.0272024 & 0.0678869 & 0.0950893 \\
\hline Sweetness & 0.2410714 & 0 & 0.1428571 & 0.6071429 & 0.7500000 \\
\hline Overall & 0.1573586 & -0.0115179 & 0.0366964 & 0.0968750 & 0.1335714 \\
\hline Total score & 16.2101023 & -0.3052679 & 1.9167857 & 4.1076786 & 6.0244643 \\
\hline \multicolumn{6}{|l|}{ Physical quality } \\
\hline $\begin{array}{l}\text { Hundred bean } \\
\text { weight }(\mathrm{g})\end{array}$ & 1.2724959 & 0.1029603 & 0.7012743 & 0.4126583 & 1.1139326 \\
\hline
\end{tabular}


Table 4. Minimum, maximum, median, mean, standar of deviation and genetic components of organoleptic and physical quality

\begin{tabular}{|c|c|c|c|c|c|c|c|c|c|c|}
\hline Parameter & Minimum & Maximum & Median & Mean & $\mathrm{s}_{\mathrm{d}}$ & $\begin{array}{l}\mathrm{GCV} \\
(\%)\end{array}$ & $\begin{array}{l}\mathrm{PC} \\
\mathrm{V} \\
(\%)\end{array}$ & $\begin{array}{l}\mathrm{H}^{2} \mathrm{bs} \\
(\%)\end{array}$ & GA & $\begin{array}{l}\text { GAM } \\
(\%)\end{array}$ \\
\hline \multicolumn{11}{|l|}{$\begin{array}{l}\text { Organoleptic } \\
\text { quality }\end{array}$} \\
\hline Fragrance/Aroma & 7.23 & 9.03 & 8.02 & 8.18 & 0.15 & 2.47 & 4.45 & 30.72 & 0.23 & 2.82 \\
\hline Flavor & 7.13 & 8.80 & 7.89 & 7.96 & 0.15 & 2.69 & 4.60 & 34.11 & 0.26 & 3.24 \\
\hline Aftertaste & 7.53 & 8.93 & 7.95 & 8.07 & 0.16 & 2.21 & 4.61 & 22.94 & 0.18 & 2.18 \\
\hline Acidity & 7.53 & 8.90 & 7.99 & 8.05 & 0.12 & 1.50 & 3.34 & 20.02 & 0.11 & 1.38 \\
\hline Body & 7.38 & 8.88 & 8.00 & 8.04 & 0.13 & 2.11 & 3.78 & 31.08 & 0.20 & 2.43 \\
\hline Balance & 7.85 & 8.95 & 8.05 & 8.17 & 0.13 & 2.02 & 3.77 & 28.61 & 0.18 & 2.23 \\
\hline Sweetness & 7.23 & 9.03 & 8.02 & 8.77 & 0.39 & 4.31 & 9.88 & 19.05 & 0.34 & 3.88 \\
\hline Overall & 7.48 & 9.03 & 8.05 & 8.26 & 0.16 & 2.32 & 4.42 & 27.47 & 0.21 & 2.51 \\
\hline Total score & 78.00 & 91.68 & 82.27 & 83.64 & 1.01 & 1.66 & 2.93 & 31.82 & 1.61 & 1.93 \\
\hline \multicolumn{11}{|l|}{ Physical quality } \\
\hline $\begin{array}{c}\text { Hundred bean } \\
\text { weight }(\mathrm{g})\end{array}$ & 12.42 & 18.32 & 14.32 & 14.27 & 0.32 & 5.87 & 7.40 & 62.95 & 1.37 & 9.61 \\
\hline
\end{tabular}

$\mathrm{Sd}_{\mathrm{d}}=$ standard of deviation, $\mathrm{GCV}=$ genotypic coefficient of variation, $\mathrm{PCV}=$ phenotypic coefficient of variation, $\mathrm{H}^{2} \mathrm{bs}=$ coefficient of heritability in broad sense, $\mathrm{GA}=$ genetic advance, GAM = genetic advance in percentage of mean.

Contrary to this reseach result, Tessema et al. (2011) and Kitila et al. (2011) generally found higher genetic and phenotypic variability. Fragrance/aroma, flavor, aftertaste, acidity, body, uniformity, balance, sweetness, overall and total score had low heritability. Acidity had the highest heritability. Fragrance/aroma, flavor, aftertaste, acidity, body, uniformity, balance, sweetness, overall and total score showed low genetic advance. Hundred bean weight had moderate genetic advance. Flavor had the highest genetic advance. Bean weight performed moderate genetic advance. Genotypic variability is the basis for the plant breeding to create better phenotypes of plants. Aftertaste could be transmitted to the progeny $(\mathrm{H} 2 \mathrm{bs}=22.94 \%)$ in which total score would be expected to have genetic advance (GAM) $2.51 \%$. However, phenotypic selection for fragrance/aroma, flavor, aftertaste, acidity and body might be difficult to be carried out in this coffee population due to low phenotypic variation along with low genotypic variability (Table 4). Contrary to this research, Tessema et al. (2011) and Kitila et al. (2011) found moderate to high genotypic and phenotypic variability. In future research, crossbreeding should be conducted to create higher genotypic and phenotypic variation. Soebreira et al. (2016) revealed that breeding might improve beverage quality.

Leroy et al. (2006) and Soebreina et al. (2016) concluded that interspecific hybridization or crossing within species might increase genetic gains for organoleptic quality. Bertrand et al. (2006) revealed that the clones of F1 hybrids had higher aroma, body and acidity in comparison with traditional cultivars. This research result and Chalfoun et al. (2013) showed that genotypes could have superior beverage quality with total score above 80 . The certain consumers needed specific taste (Leroy et al., 2006).

\section{Conclusion}

Low genotypic and phenotypic variability in most of the organoleptic qualities were found in these genotypes of Arabica coffee.

\section{Acknowledgement}

This research was supported by Goldenways Coffee Company (Nr GC/1/III/2012).

\section{References}

Bertrand, B., Vaast, P., Alpizar, E., Etienne, H., Davrieux, F., Charmetant, P., 2006. Comparison of bean biochemical composition and beverage quality of Arabica hybrids involving Sudanese-Ethiopian origins with traditional varieties at various elevations in Central America. Tree Physiology, 26: 1239-1248

Chalfoun, S.M., Pereira, M.C., Carvalho, G.R., Pereira, A.A., Savian, T.V., Botelho, D.M.D.S., 2013. Sensorial characteristics of coffee (Coffea arabica L.) varieties in the Alto Paranaíba region. Coffee Science, Lavras, 8(1): 43-52.

DGEC. 2015. Tree Crop Estate Statistics of Indonesia 2014-2016, Coffee [In Indonesian: Statistik Perkebunan Indonesia 2014-2016, Kopi]. Dirjen Perkebunan, Jakarta. 97p. Available at http://ditjenbun.pertanian.go.id/tinymcpuk/gambar/fi le/statistik/2016/KOPI.pdf. 
Kathurima, C.W., Gichimu, B.M., Kenji, G.M., Muhoho S.M., Boulanger, R., 2015. Evaluation of beverage quality and green bean physical characteristics of selected Arabica coffee genotypes in Kenya. African Journal of Food Science, 3(11): 365-371. Available at https://agritrop.cirad.fr/552843/1/document_ 552843.pdf

Kitila, O., Alamerew, S., Kufa, T., Garedew, W., 2011. Organoleptic Characterization of Some Limu Coffee (Coffea arabica L.) Germplasm at Agaro, Southwestern Ethiopia. Int. J. Agric. Res., 6(7): 537549. DOI:10.3923/ijar.2011.537.549

Leroy, T., Ribeyre, F., Bertrand, B., Charmetant, P., Dufour, M., Montagnon, C., Marraccini, P., Pot, D. 2006. Genetics of coffee quality. Braz. J. Plant Physiol., 18(1): 229-242.

Mawardi, S., Hulupi, R., Wibawa, A., Wiryadiputra, S.Y., 2008. Guide for cultivation and processing of Gayo Arabica coffee [In Indonesian: Panduan Budidaya dan Pengolahan Kopi Arabica Gayo]. ICCRI. Jember. 205p.

Mayo, O., 1987. The Theory of Plant Breeding. Oxford Univ. Press. New York. 334p.

Poehlman, J.M., 1987. Breeding field crops. AVI Publ. Co., Inc. Westport. 724p.

Quinn, G.P., Keough, M.J., 2002. Experimental design and data analysis for biologists. Cambridge Univ. Press, NY. 537p.

SCAA. 2009. Specialty Coffee Association of America Cupping Protocols (Revised: November 21, 2009). Available at https://www.scaa.org/PDF/PR\%20-

\section{$\% 20$ CUPPING\%20}

PROTOCOLS\%20V.21NOV2009A.pdf

Sobreira, F.M., Oliveira, A.C.B.D., Pereira, A.A., Guarçoni, M.G., Sakiyama, N.S., 2016. Divergence among Arabica coffee genotypes for sensory quality. AJCS 10(10):1442-1448. DOI: 10.21475/ajcs.2016.10.10.p7430

Tessema, A., Alamerew, S., Kufa, T., Garedew, W., 2011. Variability and association of quality and biochemical attributes in some promising Coffea arabica germplasm collection in Southwestern Ethiopia. Int. J. Plant Breed. Gen., 5(4): 302-316.

Wahyudi, T., Pujiyanto, M., 2016. Coffee : history, botany, production process, processing, downstream production, partnership syastem [In Indonesian: Kopi : sejarah, botani, proses produksi, pengolahan, produksi hilir, dan sistem kemitraan]. Gadjah Mada University Press. Yogyakarta. 890p.

Welde M. G., Alamerew, S., Kufa, T., 2015. Genetic Diversity Analysis of Some Ethiopian Specialty Coffee (Coffea arabica L.) Accessions for Cup Quality Attributing Traits. J. of Biology, Agriculture and Healthcare, 5(5): 88-96.

Yusianto. 2008. Wet Process and dry process (West India Model/WIB] [In Indonesian: Pengolahan Basah Penggerbusan Kering (Model Pengolahan Hindia Barat/WIB)] in Mawardi S., Hulupi R.,, Wibawa A.,, Wiryadiputra, S., Yusianto (eds.): Guide for cultivation and processing of Gayo Arabica coffee (In Indonesian: Panduan Budidaya dan Pengolahan Kopi Arabica Gayo). p142-147. ICCRI, Jember 